\title{
СИНДРОМ ПРОФЕСІЙНОГО ВИГОРАННЯ У СПІВРОБІТНИКІВ ВІДДІЛЕННЯ ІНТЕРВЕНЦІЙНОЇ КАРДІОЛОГІЇ
}

\author{
М.-В. А. Штинь ${ }^{1}$, І. М. Маланчин ${ }^{2}$ \\ ${ }^{1}$ КНП «Обласна клінічна лікарня Івано-Франківської обласної ради» \\ ${ }^{2}$ Тернопільський національний медичний університет \\ імені І. Я. Горбачевського МОЗ Украӥни
}

\begin{abstract}
Дана стаття містить результати обстежень медичних працівників відділення інтервенційної кардіології щодо виникнення у них синдрому емоційного вигорання. Варто зазначити, що рівень професійної мотивації був тотожний показникам професійного вигорання. У жодного працівника відділення інтервенційної кардіології не було виявлено вкрай низького рівня професійної мотивації.
\end{abstract}

\section{PROFESSIONAL BURNOUT SYNDROME AMONG MEDICAL PERSONNEL OF INTERVENTIONAL CARDIOLOGY DEPARTMENT}

\author{
M.-V. A. Shtyn ${ }^{1}$, I. M. Malanchyn ${ }^{2}$ \\ ${ }^{1}$ Ivano-Frankivsk Regional Clinical Hospital \\ ${ }^{2}$ I. Horbachevsky Ternopil National Medical University
}

The article analyzes the results of the occurrence of emotional burnout syndrome among medical personnel of the Interventional Cardiology Department. It should be noted that the level of professional motivation was identical to the indicators of professional burnout. Not a single employee of the Department of Interventional Cardiology showed extremely low levels of professional motivation.

Вступ. Емоційне вигорання - це сформований особистістю механізм психологічного захисту в формі повного або часткового виключення емоцій (зниження їх енергетики) у відповідь на обрані психотравмувальні дії. Синдром емоційного вигорання пов'язаний з професійною діяльністю, яка передбачає постійну взаємодію з людьми [1, 4]. На вигорання неабияке значення мають вік, стаж роботи та задоволеність кар'єрою. Це детально описано у праці Н. Е. Водопьянова «Синдром выгорания: диагностика и профилактика» та наглядно продемонстровано у даному дослідженні. Вплив віку на ефект вигорання $\epsilon$ неоднозначним. У деяких дослідженнях виявлено схильність до вигорання осіб не тільки старшого, але й молодого віку. В окремих випадках стан останніх пояснюється емоційним шоком, який вони відчувають, коли розуміють реальний стан справ, часто не відповідний їхнім очікуванням відносно професійної діяльності. У процесі збільшення рівня вигорання

(c) М.-В. А. Штинь, І. М. Маланчин, 2020 збільшується кількість симптомів, оскільки попередні не зникають. Згодом це призводить до зниження інтересу до своєї діяльності та порушення міжособистісних зв'язків як на роботі, так і в особистому колі $[2,5]$.

Основна частина. У даному дослідженні обстежено 20 медичних працівників відділення інтервенційної кардіології. Серед них було 15 жінок (75 \%) та 5 чоловіків (25\%). Респондентів поділено за професіями: 5 лікарів (25\%), 10 медичних сестер (50\%), 5 молодших медичних працівників (25\%). Також до уваги брали вік обстежених, їх поділили таким чином: 20-29 років - 7 (35\%), 30-39 років - 5 (25\%), 40-49 років - 4 (20\%), 50-60 років - 4 (20\%). Стаж роботи 0-10 років мали 8 (40\%) осіб, 10-20 років - 6 (30\%), 20-30 років - 5 (25\%), 30-40 років - 1 (5\%).

У дослідженні ми використовували опитувальник «Визначення психічного «вигорання» О. О. Рукавішнікова. Опитувальник містив 72 запитання, чотири варіанти відповідей - «ніколи», «зазвичай», «рідко» та «часто». Працівники відділення відповідали на за- 
питання, орієнтуючись на власні відчуття стосовно роботи, робили це якомога швидше, довго не думаючи над відповіддю. Ця методика має 3 характеристики.

Психоемоційне виснаження (ПВ) - процес вичерпання емоційних, фізичних, енергетичних ресурсів професіонала, який працює з людьми. Виснаження проявляється у хронічній емоційній і фізичній втомі, байдужому та холодному ставленні до людей з ознаками депресії та роздратованості.

Особистісне віддалення (OB) - специфічна форма соціальної дезадаптації професіонала, який працює з людьми. Особистісне віддалення характеризується зменшенням кількості контактів з оточенням, підвищенням роздратованості й нетерплячості в ситуаціях спілкування, негативізмом стосовно інших.

Професійна мотивація (ПМ) - рівень робочої мотивації та ентузіазму щодо роботи альтруїстичного змісту. Стан емоційної сфери оцінюють за таким показником, як продуктивність професійної діяльності, оптимізм і зацікавленість у роботі, самооцінка професійної діяльності та ступеня успішності в роботі з людьми.

Для визначення ПВ використовують 25 тверджень із опитувальника. Для визначення ОВ застосовують 24 твердження з анкети. Для оцінки ПМ застосовують 23 твердження з опитувальника. Для всіх компонентів існують свої норми. Тест передбачає п'ять рівнів сформованості: «вкрай високий», «високий», «середній», «низький» і «вкрай низький» [3].

Проаналізувавши результати опитування працівників відділення інтервенційної кардіології можна дійти висновку, що вкрай високі значення за шкалою «психоемоційне виснаження» були у однієї медичної сестри (5\%). Високий рівень був у 4 (20\%) співробітників, із них 3 (15\%) медичні сестри та один молодший медичний працівник (5\%). Середні значення були в 9 (45\%) респондентів, з яких 4 (20\%) медичні сестри, 3 (15\%) лікаря та 2 (10\%) молодші медичні працівники. Низькі значення були в 4 (20\%) працівників, з яких один (5\%) лікар, одна (5 \%) медична сестра та 2 (10\%) молодші медичні працівники.

Вкрай високі значення за компонентом «особистісне віддалення» не було виявлено у жодного працівника. Високі значення були лише в 3 (15\%) медичних сестер. Середні значення мали 11 (55 \%) працівників, з яких більшість, а саме 6 (30 \%) осіб, медичні сестри. Низькі значення компонента «особистісне віддалення» виявлено в 5 (25\%) співробітників, з них 2 (10\%) лікаря, 2 (10\%) санітарки та одна (5 \%) медична сестра. Вкрай низькі значення мав один (5 \%) лікар.
Вкрай високі значення компонента «професійна мотивація» були в 2 (10\%) медичних сестер. Високі значення мали 7 (35\%) працівників, переважно медичні сестри, а саме 4 (20\%), а також 2 (10\%) лікарів та один (5\%) молодший медичний працівник. Середні значення компонента були в 10 (50 \%) працівників, 3 яких 3 (15\%) лікаря, 4 (20\%) медичні сестри та 3 (15\%) - молодший персонал. Низькі значення виявлено в одного (5 \%) молодшого медичного працівника. Вкрай низькі значення не було виявлено у жодного працівника відділення інтервенційної кардіології.

Високі та вкрай високі показники компонента «психоемоційне виснаження» мали лише 5 (25\%) респондентів жіночої статі. Вкрай низькі та низькі значення були в 6 (30 \%) працівників, однаково у жінок та чоловіків. Середні значення виявили в 9 (45\%) працівників, з яких більшість жінки.

Аналізуючи результати опитування компонента «особистісне віддалення», виявлено переважання середніх показників серед співробітниць. Цей результат мав місце в 11 (55 \%) працівників відділення: 9 (45 \%) жінок та 2 (10\%) чоловіків. Високі значення мали тільки 3 (15\%) жінок. Вкрай низькі значення мав лише один (5\%) респондент чоловічої статі. Низькі значення були у 2 (10\%) жінок та 2 (10 \%) чоловіків.

Високі та вкрай високі значення компонента «професійна мотивація» були в 9 (45\%) працівників, з яких 7 (35\%) жінок та 2 (10\%) чоловіків. Середній показник був у 10 (50 \%) працівників, з яких більшість співробітниці - 7 (35\%). Низькі значення мала одна співробітниця.

Для кращого аналізу синдрому професійного вигорання працівників відділення інтервенційної кардіології, ми вирішили проаналізувати показники всіх компонентів залежно від віку респондентів. Вкрай високе значення компонента ПВ мав лише один працівник віком 20-30 років. Високі значення мали 4 (20\%) співробітники, по двоє респондентів віком 20-30 та 30-40 років. Середні значення мали 9 (45\%) працівників, більшість з яких були віком 20-30 років. Низькі та вкрай низькі значення виявили у співробітників трьох вікових груп: 30-40 років у одного (5\%) працівника, 40-50 років - у 3 (15\%) та 50-60 років - в 2 (10\%) осіб. У віковій групі 20-30 років не виявлено жодного показника.

Якщо проаналізувати результати опитування компонента «особистісне віддалення», можна констатувати, що вкрай низькі та низькі значення мали 6 (30\%) працівників, з яких переважала вікова група 40-50 ро- 
ків. На рахунок середніх показників, то тут найменше було працівників у віковій категорії 40-50 років, всього одна особа. Середні показники компонента ОВ мали співробітники вікової категорії 30-40 та 50-60 років по 3 (15\%) особи. Найбільше працівників було у віковій категорії 20-30 років-4 (20\%). Низькі значення ОВ мали всі вікові категорії. Вкрай низькі значення були тільки у однієї людини у віковій категорії 40-50 років.

Високі та вкрай високі значення компонента ПМ мали 9 (45\%) респондентів, у однаковій кількості, по 4 (20 \%) працівники, для вікової категорії 20-30 та 3040 років. Середні значення за кількістю співробітників були однаковими для таких вікових груп: 20-30, 40-50 та 50-60 років - по 3 (15\%) працівники відповідно. Низькі значення компонента ПМ були наявні тільки в одного працівника з категорії 40-50 років. Вкрай низькі значення не виявлено у жодного працівника.

\section{СПИСОК ЛІТЕРАТУРИ}

1. Бойко В. В. Энергия эмоций в общении: взгляд на себя и на других / В. В. Бойко. - М. : Наука, 1996. - 87 с.

2. Водопьянова Н. Е. Синдром выгорания: диагностика и профилактика / Н. Е. Водопьянова. - СПб. : Питер, 2008. - 56 c.

3. Фетискин Н. П. Социально-психологическая диагностика развития личности и малых групп / Н. П. Фетискин, В. В. Козлов, Г. М. Мануйлов. - М. : Изд-во Института психотерапии, 2002. - С. 249-252.
Отже, аналізуючи дані результати, можна зробити висновок, що у працівників відділення інтервенційної кардіології $\epsilon$ прояви синдрому професійного вигорання. Проте вкрай високі значення виявлено тільки в одного працівника відділення. Переважала вікова категорія 20-30 років та респонденти жіночої статі.

Висновки. Синдром професійного вигорання найвираженіший у працівників вікової категорії 20-30 років, серед медичних сестер, респондентів жіночої статі. Рівень професійної мотивації був тотожний показникам професійного вигорання. У жодного працівника відділення інтервенційної кардіології не виявлено вкрай низького рівня професійної мотивації. Оскільки стан емоційного здоров'я працівників безпосередньо впливає на їхню роботу, необхідно вчасно виявляти синдром професійного вигорання.

4. Голуб О. В. Стресова стійкість: сутність, теоретичні основи формування / О. В. Голуб // Збірник наукових праць Інституту психології ім. Г. С. Костюка АПН України ; за ред. С. Д. Максименка. - 2004. - Т. VI, Вип. 15. - С. 301.

5. Молокоедов А. В. Эмоциональное выгорание в профессиональной деятельности / А. В. Молокоедов, С. В. Удовик, И. М. Слободчиков. - ООО «Левъ», 2018. - Глава 2 : Особенности проявления синдрома эмоционального выгорания и его симптомы.

Отримано 22.01.20 